\title{
HYDRATION WITH MALTODEXTRIN VS. A REGIONAL BEVERAGE: EFFECTS ON THE PERFORMANCE OF SOCCER PLAYERS
}

\author{
HIDRATAÇÃO COM MALTODEXTRINA VS. BEBIDA REGIONAL: EFEITOS NO DESEMPENHO \\ DE JOGADORES DE FUTEBOL
}

Original Article

ARTIGO ORIGINAL

Artículo Original

\section{HIDRATACIÓN CON MALTODEXTRINA VS. BEBIDA REGIONAL: EFECTOS SOBRE EL RENDIMIENTO DE JUGADORES DE FÚTBOL}

\begin{abstract}
Juliana Tanise Costa Câmara (Nutritionist)

Amanda Maria de Jesus Ferreira ${ }^{2}$ (Nutritionist and Physical Education Professional)

Ana Paula Trussardi Fayh ${ }^{2}$ (Nutritionist, Physical Education Professional and Endocrinologist)

1. Universidade Federal do Rio Grande do Norte, Faculdade de Ciências da Saúde de Trairi, Santa Cruz, RN, Brazil.

2. Universidade Federal do Rio Grande do Norte, Centro de Ciências da Saúde, Departamento de Nutrição, Natal, RN, Brazil.
\end{abstract}

\section{Correspondence:}

Ana Paula Trussardi Fayh

Universidade Federal do Rio Grande do Norte, Centro de Ciências da Saúde, Departamento de Nutrição. Av. Senador Salgado Filho, 3000, Campus Universitário, Natal, RN, Brazil. 59078-970.

apfayh@yahoo.com.br

\section{ABSTRACT}

Introduction: It is known that ingestion of carbohydrate-containing beverages can enhance sports performance. However, many teams do not have sufficient financial resources to invest in commercial products and need to prepare their own hydration drinks. Jacuba is a beverage used as sport drink (source of carbohydrate) in soccer clubs in Northeastern Brazil. Objective: To evaluate the influence of two beverages with carbohydrate on blood glucose, dehydration and fatigue in a soccer team of Northeastern Brazil. Methods: Twenty-two soccer players were evaluated in two days of physical training, with ingestion of water ad libitum and two beverages: 1) maltodextrin-based drink, or 2) Jacuba. Capillary blood glucose was measured before and after training. Fatigue was assessed using Borg Scale after exercise. To evaluate the dehydration of the athletes at the end of exercise, the urinalysis test and the verification of the body mass change during the training were performed. Results: Blood glucose changed to $13.1 \pm 29.5 \mathrm{mg} / \mathrm{dL}$ and $7.6 \pm 22.2 \mathrm{mg} / \mathrm{dL}$ on training days with consumption of maltodextrin and Jacuba, respectively, without statistical significance. There were no changes in body mass and in water and total fluids intake in the two days of training. The Borg Scale score after training was $15.2 \pm 2.6$ and 14.9 \pm 3.0 for maltodextrin and Jacuba, respectively $(p=0.12)$. Conclusion: Jacuba can be used to improve hydration and maintain blood glucose in soccer players because their results do not differ with those of maltodextrin-based drink.

Keywords: soccer; carbohydrates; blood glucose; fatigue; dehydration.

\section{RESUMO}

Introdução: Sabe-se que ingestão de bebidas que contêm carboidrato pode aprimorar o desempenho esportivo. No entanto, muitos times não têm recursos financeiros suficientes para investir em produtos comerciais e precisam preparar suas próprias bebidas de hidratação. Jacuba é usada como bebida esportiva (fonte de carboidrato) em clubes de futebol no Nordeste do Brasil. Objetivo: Avaliar a influência de duas bebidas com carboidrato sobre glicose sanguínea, desidratação e fadiga em um time de futebol do Nordeste do Brasil. Métodos: Foram avaliados 22 jogadores de futebol em dois dias de treinamento físico, com ingestão de água à vontade e duas bebidas: 1) bebida à base de maltodextrina, ou 2) Jacuba. A glicemia capilar foi medida antes e depois do exercício. A fadiga foi avaliada usando a Escala de Borg após o exercício. Para verificar a desidratação dos atletas no final do treino, realizou-se o teste de urinálise e a verificação da alteração da massa corporal durante o treinamento. Resultados: A glicose san-

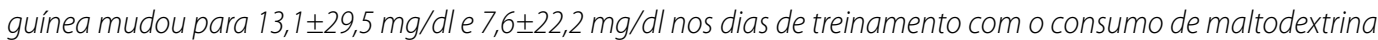
e Jacuba, respectivamente, sem significância estatística. Não houve mudanças na massa corporal e no consumo de água e de líquidos totais nos dois dias de treinamento. A pontuação da Escala de Borg após o treinamento foi

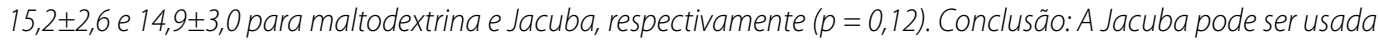
para melhorar a hidratação e manter a glicose sanguínea em atletas de futebol, porque seus resultados não diferem da bebida com maltodextrina.

Descritores: futebol; carboidratos; glicemia; fadiga; desidratação.

\section{RESUMEN}

Introducción: Se sabe que la ingestión de bebidas que contienen carbohidratos puede mejorar el rendimiento deportivo. Sin embargo, muchos equipos no tienen suficientes recursos financieros para invertir en productos comerciales y tienen que preparar sus propias bebidas de hidratación. Jacuba es utilizada como una bebida deportiva (fuente de carbohidratos) en los clubes de fútbol del Nordeste de Brasil. Objetivo: Evaluar la influencia de dos bebidas con carbohidratos en glucosa en la sangre, deshidratación y fatiga en un equipo de fútbol en el Nordeste de Brasil. Métodos: Se evaluó un total de 22 jugadores de fútbol en dos días de entrenamiento físico, con la ingesta de agua sin restricción y dos bebidas: 1) la bebida a base de maltodextrina, o 2) Jacuba. La glucosa en la sangre capilar se midió antes y después del ejercicio. La fatiga se evaluó mediante la escala de Borg después del ejercicio. Para evaluar la deshidratación de los atletas en el final del entrenamiento se llevó a cabo un análisis de orina y la verificación del cambio en la masa corporal durante

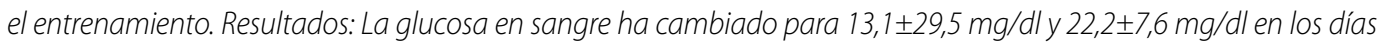


de entrenamiento con el consumo de maltodextrina y Jacuba, respectivamente, sin significación estadistica. No hubo cambios en el peso corporal y el consumo de agua y líquidos totales en los dos días de entrenamiento. La puntuación de

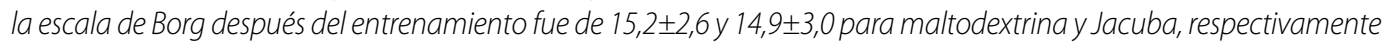
$(p=0,12)$. Conclusión: Se puede utilizar Jacuba para mejorar la hidratación y mantener la glucosa en sangre en jugadores de fútbol, debido a que sus resultados no fueron diferentes de la bebida con maltodextrina.

Descriptores: fútbol; carbohidratos; glucemia; fatiga; deshidratación.

\section{INTRODUCTION}

Soccer is characterized by periods of high-intensity, followed by periods of sub-maximal effort. Depending of your position athletes can run above $10 \mathrm{~km}$ during a match ${ }^{1,2}$. Soccer players sprint to tackle an opponent or gain possession of the ball, dribble it before passing and then jog into position to support an attack or defense. These sprints are rarely longer than 3-4s followed by recovery of no more than several seconds before players are in action again ${ }^{3}$. Thus, these prolonged periods of multiple sprints can drain muscle glycogen stores, leading to a decrease in power output and a reduction in general work rate during training and competition ${ }^{4,5}$.

Soccer is currently the world's most popular sport, and so in the last decades countless studies have been published on its various aspects ${ }^{6,7}$ including nutritionals ${ }^{8}$. Given the well-documented importance of nutrition in optimizing performance and health, it is somewhat surprising that the nutritional intake of soccer players, particularly male players, has been systematically described as inadequate ${ }^{8,9}$.

In addition an adequate ingestion of carbohydrate, fluid intake and adequate hydration during exercise are essential and, more importantly, critical during prolonged training sessions and competition events. For events lasting longer than $1 \mathrm{~h}$, athletes should consume fluids containing carbohydrates and electrolytes rather than water alone ${ }^{10}$. There are several recent relevant studies on carbohydrate and performance in different sports as well as the recommended amounts of dietary carbohydrate or carbohydrate-electrolyte gels that supports training and competition ${ }^{5,9,11}$. These nutritional recommendations must be observed in order to improve the physical performance of athletes.

The nutritional ergogenic commerce resources is expanding in recent years, with an increasing number of available products with carbohydrate. However, especially in developing countries as Brazil, many teams do not have sufficient financial resources for investment in commercial products and need to prepare their own hydration drinks. Jacuba is an alternative beverage prepared with water, lemon and acerola (typical food of Northeastern of Brazil) juice and brown sugar that is used as sport drink (source of carbohydrate) in soccer clubs in Northeastern Brazil. Although this beverage is widely used in many football clubs, there are no studies showing its effectiveness on performance parameters, hydration and maintenance of blood glucose. Therefore, the aim of this study was to evaluate the intake of Jacuba on blood glucose, dehydration and fatigue during the session of physical training of soccer's athletes.

\section{METHODS}

Twenty-two male soccer players (aged 19-37 years) were recruited, for a descriptive cross-sectional study, from a team of Northeastern Brazil. All the players were invited to take part in the study and all agreed to participate. The participants signed an informed consent form and ethical approval by Ethics Committee in Research of the Federal University of Rio Grande do Norte (310.172, CAAE 02511013.0.0000.5537). At the time of the study, players were participating the regional championship and trained for 5 days per week, 4h per day, plus one match per week.

Data collection was performed in two days of typical physical training, with the interval of 72 hours between them, in the same weather conditions ( 32 and $33^{\circ} \mathrm{C}$ temperature, and $58-57 \%$ relative humidity). Intensity and duration of the training session were kept unchanged in both days. The training sessions have occurred in the afternoon, lasting 90 minutes except heating. In each day training was offered water ad libitum and an additional beverage: 1) maltodextrin-based beverage; or 2) regional beverage (Jacuba) made with lemon and acerola juice and brown sugar. Further details on the nutritional composition of the two beverages are shown in Table 1. Each player had his own bottle being allowed to drink ad libitum. The amount ingested was then measured individually. Players were instructed to not wet their heads with their water nor throw it away. During previous training sessions and friendly matches, they had the opportunity to familiarize themselves with this procedure.

Body composition of the players was determined by the anthropometric technique, with skin folds measurement. Nutritional status was classified according to the calculation of Body Mass Index ${ }^{12}$. Fat percentage was determined by the Jackson and Pollock formula ${ }^{13}$ and the lean mass was determined by the reduction of fat percentage of the total weight.

Change in the hydration status during the experimental tests was assessed by two methods: change in body mass and urinalysis. Players were weighed before (Wb) and after (Wa) the training session (Filizola R scale - MF 100, Brazil), while wearing just their shorts and football socks - these were also weighed and their values were subtracted from the total weight. Weight loss was calculated as Wb - Wa. Percentage of dehydration was calculated by the formule (Wa - Wb)/100. Immediately after the training sessions, urine sample $(80 \mathrm{~mL})$ was collected from each player and analyzed by reflectance photometer Uriquest R500 (Labtest, Brazil). For glucose blood monitoring, fingertip blood samples were taken immediately before and after sessions training for measurement of capillary glucose (Accu Check Advance, Roche, Germany).

Table 1. Ingredients and nutritional composition of the beverages offered during physical training, in $100 \mathrm{~mL}$.

\begin{tabular}{c|c|c|c|c|c}
\hline & & $\begin{array}{c}\text { Energy } \\
\text { (kcal) }\end{array}$ & $\begin{array}{c}\text { Carbohydrate } \\
\text { (g) }\end{array}$ & $\begin{array}{c}\text { Protein } \\
\text { (g) }\end{array}$ & $\begin{array}{c}\text { Lipid } \\
\text { (g) }\end{array}$ \\
\hline Reginal beverage (Jacuba) & & & & & \\
\hline Lemon juice & $10 \mathrm{~mL}$ & 2.0 & 0.5 & - & - \\
\hline Acerola juice & $20 \mathrm{~mL}$ & 5.6 & 1.4 & - & - \\
\hline Brown Sugar & $15 \mathrm{~g}$ & 48.0 & 12 & - & - \\
\hline Water & $60 \mathrm{~mL}$ & - & - & - & - \\
\hline Total & & 55.6 & 13.9 & - & - \\
\hline Maltodextrin-based beverage & & & & & \\
\hline Maltodextrin (Athletica ${ }^{\circledR}$ ) & $10 \mathrm{~g}$ & 38.0 & 9.5 & - & - \\
\hline Total & & 38.0 & 9.5 & - & - \\
\hline
\end{tabular}


Two instruments were applied after each session's training to evaluated the fatigue of the athletes: 6-20 Borg Perceived exertion ${ }^{14}$ and Brunel Mood Scale ${ }^{15}$. The assessment included "how much exertion did you actually experience during this trial of exercise?". The Brunel Mood Scale consists of twenty-four simple mood indicators, composed of six subscales: stress, depression, anger, vigor, fatigue and confusion. Their findings help to understand how feelings and psychological energy optimize sports performance ${ }^{16}$.

\section{Statistical analyses}

Statistical analyses were performed using IBM SPSS (version 21.0, SPSS Inc., Chicago, USA). Shapiro-Wilk's test was conducted to assess normality of data. All results were reported as mean \pm standard deviation (SD). Independent $t$-test or Mann-Whitney test were used to compare differences between two different days of training variables. Differences between before and after sessions of training variables were analyzed using paired Student t-test or Wilcoxon. Statistical significance was accepted at $p<0.05$.

\section{RESULTS}

Characteristics of the subjects are listed in Table 2. Subjects were considering a body composition consistent with the sport practiced according with body mass index and fat percentage. Total consumption of liquid and test beverages were similar in the two days of intervention.

Regarding the changes in glycemic control of athletes, there is significant elevation of blood glucose in two days of training, but no differences between the days of intervention $(p=0.08)$. Figure 1 illustrates the change in blood glucose before and after training.

In two days of training there was little change in body mass of athletes before and after the exercise, noting that the amount of ingested drink was enough to replenish fluid losses. In the first moment (drink with maltodextrin) the average weight of athletes ranged from $74.0 \pm 7.6 \mathrm{~kg}$ to $73.6 \pm 7.5 \mathrm{~kg}(\mathrm{p}=0.78)$, and in the second session (Jacuba) of $74.4 \pm 7.4 \mathrm{~kg}$ para $73.7 \pm 7.5 \mathrm{~kg}(p=0.65)$. No difference

Table 2. Baseline characteristics of study group.

\begin{tabular}{c|c}
\hline Athletes & Mean \pm SD \\
\hline Age (years) & $24.9 \pm 5.1$ \\
\hline Weight $(\mathrm{kg})$ & $74.7 \pm 7.4$ \\
\hline Height $(\mathrm{m})$ & $1.77 \pm 0.05$ \\
\hline BMl $\left(\mathrm{kg} / \mathrm{m}^{2}\right)$ & $23.6 \pm 1.9$ \\
\hline Lean Mass $(\mathrm{kg})$ & $67.2 \pm 5.3$ \\
\hline Fat Percentage (\%) & $9.8 \pm 3.5$ \\
\hline
\end{tabular}

$\mathrm{SD}=$ standard deviation; $\mathrm{BMI}=$ Body Mass Index.

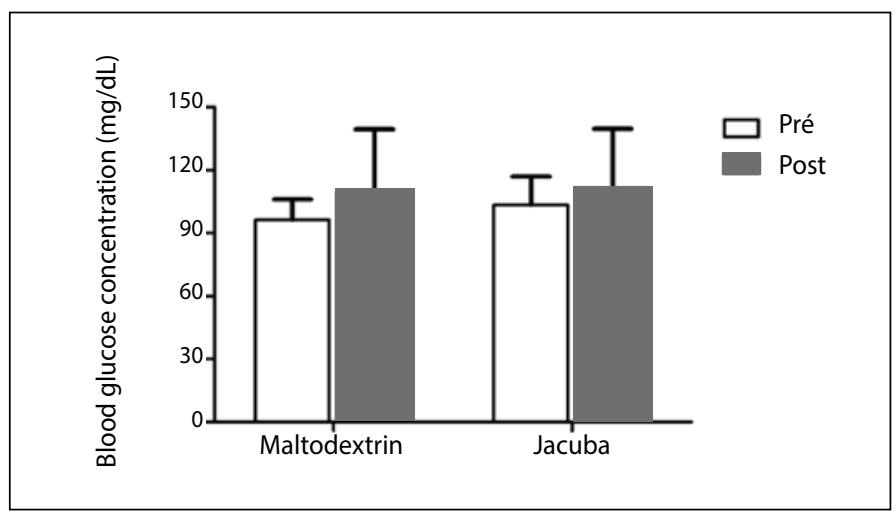

Figure 1. Blood glucose before and after physical training with consumption of different beverages. No statistical significant difference in the moments. for any parameters of urine analysis, including specific gravity and $\mathrm{pH}$ was found in the sessions. Table 3 shows the results of glycaemia and dehydration in both sessions.

Regarding the fatigue results, evaluated by applying the scales, there were no statistically significant differences between sessions of training. However when making analysis of each dimensions of Brunel Mood Scale, it is clear that "fatigue" item of this scale had higher scores on the day when the athletes consumed water and Jacuba compared daily water intake and maltodextrin $(p=0,04)$. Table 4 shows the changes of fatigue in athletes with the application of these scales.

Table 3. Changes glycaemia, hydration parameters, and fluids consumption in the two days of physical training with different beverages.

\begin{tabular}{c|c|c|c}
\hline Variables & $\begin{array}{c}\text { Water }+ \\
\text { Maltodextrin }\end{array}$ & $\begin{array}{c}\text { Water }+ \\
\text { Jacuba }\end{array}$ & $\mathbf{p}$ \\
\hline Changes in glycaemia $(\mathrm{mg} / \mathrm{dL})$ & $13.1 \pm 29.5$ & $7.6 \pm 22.2$ & $0.08^{*}$ \\
\hline Changes in body weight $(\mathrm{kg})$ & $-0.46 \pm 0.48$ & $-0.64 \pm 0.47$ & $0.07^{*}$ \\
\hline Changes in body weight $(\%)$ & $0.64 \pm 0.64$ & $0.87 \pm 0.65$ & $0.07^{*}$ \\
\hline Water consumption $(\mathrm{mL})$ & $1453.3 \pm 461.5$ & $1315.9 \pm 480.9$ & $0.34^{*}$ \\
\hline Total consumption of fluides $(\mathrm{mL})$ & $1714.8 \pm 492.2$ & $1588.6 \pm 533.2$ & $0.07 \dagger$ \\
\hline Specific gravity of urine & $1028.4 \pm 2.4$ & $1025.0 \pm 8.9$ & $0.64^{*}$ \\
\hline Urine pH & $5.7 \pm 0.2$ & $5.9 \pm 0.3$ & $0.07^{*}$ \\
\hline
\end{tabular}

* $p$ value with Student-t test. $\uparrow p$ value Mann-Whitney test.

Table 4. Fatigue and effort perception in the two days of physical training.

\begin{tabular}{|c|c|c|c|c|}
\hline \multirow{7}{*}{ Brunel Mood Scale } & & $\begin{array}{c}\text { Water + } \\
\text { Maltodextrin }\end{array}$ & $\begin{array}{l}\text { Water + } \\
\text { Jacuba }\end{array}$ & $\mathrm{p}$ \\
\hline & Anger & $0.9 \pm 1.8$ & $2.1 \pm 3.7$ & $0.12 \dagger$ \\
\hline & Confusion & $0.6 \pm 1.2$ & $0.4 \pm 0.9$ & $0.09+$ \\
\hline & Depression & $0.1 \pm 0.3$ & $0.3 \pm 1.1$ & $0.18+$ \\
\hline & Fatigue & $4.9 \pm 3.2$ & $6.8 \pm 4.3$ & $0.04+$ \\
\hline & Stress & $1.8 \pm 2.2$ & $1.5 \pm 2.3$ & $0.34+$ \\
\hline & Vigor & $10.3 \pm 3.5$ & $9.5 \pm 4.3$ & $0.07^{*}$ \\
\hline Borg Perceived exertion & & $15.2 \pm 2.6$ & $14.9 \pm 3.0$ & $0.12^{*}$ \\
\hline
\end{tabular}

* $p$ value with Student-t test. $\uparrow \mathrm{p}$ value Mann-Whitney test.

\section{DISCUSSION}

In general, football is known to be a profitable sport that has continued growth and major revenues with sponsorship values, athletes wages and benefits widely publicized in the media. However, this is the reality of a few big clubs, because the vast majority of clubs have serious budget constraints on their payrolls, especially those from less developed countries. And this budget adjustment impacts also in the preparation of their athletes. Thus, studies like this are important to verify the effectiveness of alternative nutritional strategies adopted by some Brazilian clubs to maintain the performance of their athletes. The results of this study results showed no difference in hydration parameters and performance with the use of regional beverage compared to the beverage with maltodextrin.

In recent years, research has shown significant changes in the role of carbohydrates in sports performance ${ }^{17}$. Among the new proposals, we can find discussion about the supply of different sources of exogenous carbohydrates as a way to delay fatigue and improve performance during 
exercise. This strategy is justified by increasing the oxidation rate and better utilization of carbohydrates ${ }^{18,19}$ whereas during exercise the main factor limiting their use speed is its absorption in the intestinal lumen 20,21.

In the present study, the regional drink has in its composition a combination of glucose and fructose which may favor the performance of soccer players by the mechanism explained above, being a good substitute for conventional methods. Rowlands et al. ${ }^{22}$ suggest that the more rapid gastric emptying and increased absorption with the provision of multiple sources of carbohydrates are possible mediators of the observed positive results.

Kingsley et al. ${ }^{11}$ evaluated three strategies supply of carbohydrates on blood glucose, exercise performance and hydration status in soccer players with the aim of testing the supply of beverages with different amounts and types of carbohydrates. Solutions were offered containing 9.6\% carbohydrate-electrolyte-caffeine, 5.6\% gel electrolytes, carbohydrates or placebo drink containing electrolytes only. The authors observed that the supply of carbohydrate and electrolytes and even combined with caffeine resulted in increased glucose concentration in the blood and better performance in sprints. Despite the best results, the carbohydrate, caffeine and electrolytes solution negatively influenced the hydration status of athletes.

As for hydration aspects, it is well established that dehydration resulting from loss of body weight above $2 \%$ of initial body weight has a negative impact on exercise performance, impairs muscular endurance, mental functioning, the termal regulation and increases values temperature and heart rate in the athlete 22 .

Loss of body mass during sports practice is a real measure of hypohydration in athletes, in addition to urine density ${ }^{23}$. During interventions of this study, there were no significant amounts of body weight loss. However, urine density values showed that the players had significantly dehydrated on both days according to the Casa et al. ${ }^{22}$ classification. The athlete is well-hydrated with lower urine specific gravity values than 1,010; minimally dehydrated with values between 1,010 and 1,020; significantly dehydrated with densities between 1,020 and 1,030, and severely dehydrated with values above $1,030^{22}$.

Studies about dehydration in soccer players are held all over the world. Castro-Sepúlveda ${ }^{24}$, when analyzing 156 Chilean athletes, they found a prevalence of $98 \%$ pre-training dehydration, troubling condition that can negatively affect the performance of the athlete and increase the risk of heat-related injuries during exercise. Phillips et al. ${ }^{25}$ when investigating the state of hydration and water balance from urine and weight loss of fourteen young European elite soccer players during three consecutive training sessions, they observed that athletes already had hypohydration upon waking, with urine specific gravity values greater than 1020 and not reversed this state until the time of training. The loss of body weight had great intra-individual variation during training. However, intake of liquid ad libitum supplied approximately $71 \%$ of these losses, minimizing the effects of hypohydration ( $<1 \%$ weight loss). The results of this study are similar to the present study, that also found an adequate fluid intake during training, and that was not enough to reverse the dehydration can be detected in the urine specific gravity.

These findings reinforce the importance of stimulating the water intake at all times of the day for soccer players, once you start practicing sports in dehydration conditions cause changes in the physiological homeostasis, including reduction of blood volume, increased heart rate, increased blood osmolarity, decreased blood flow to the skin, decreased sweating rate and heat loss, increased body temperature and increased perceived exertion ${ }^{26}$

Recognizing the importance of hydration for this population, the consumption from 600 to $1,000 \mathrm{ml}$ of a 6 to $10 \%$ carbohydrate solution would be most appropriate in this situation ${ }^{27,28}$. Players who ingest carbohydrate drinks use less muscle glycogen during training, delaying the feeling of fatigue, which positively influences the performance of athletes ${ }^{29}$.

The application of stress and fatigue perception scales in scientific studies has been widespread in recent years, and there are few studies with this type of mode. Ribeiro et al. ${ }^{30}$, in Florianópolis (Brazil), evaluated the pre-competitive mood of 25 non-professional football referees, with a mean age of 33 years. The authors noted that the referees who are not patients experienced less fatigue and tension, while those with better quality of sleep were less depressed. Assistant referees had higher stress and fatigue, and those who have participated in professional games more vigorously. Age had a negative relationship with anger, confusion and tension, with the latter also negatively related with time of experience in arbitration. The analysis of perceived exertion with the application of the Borg scale showed no significant differences between the days of intervention.

This study has some methodological limitations that reduce its external validity. It is a non-randomized study, and the order of supply the beverages may have affected the results. It was not realized the collection of urine before sports practice, and it was not possible to guarantee that the athletes were well hydrated before beginning training. Another limitation of this study was the use of only subjective methods for assessing physical performance, as the application of scales at the end of the training. Thus, for future studies, it is suggested the use of other measures for the assessment of physical performance, as well as analysis of urine at the time before exercise to complement the results.

\section{CONCLUSION}

In conclusion, there were no statistically significant differences in blood glucose and perceived of exertion between days of training with different strategies. Only the dimension "fatigue" of Brunel Mood Scale had higher scores on the day when the athletes consumed water and Jacuba compared daily water intake and maltodextrin. In both strategies of hydration athletes ended the session training with low levels of urine specific gravity, indicating a possible state of dehydration. Thus, the consumption of regional drink as an alternative to maltodextrin was a valid strategy for keeping sports performance in these athletes, and possible adjustments in the electrolyte in beverages, especially sodium, may have a positive role to prevent dehydration.

\section{ACKNOWLEDGEMENTS}

The authors thank the players, coaches and research assistants (Layne Christina Benedito de Assis, Sandra Azevedo Queiroz, Paloma Oliveira da Cruz, Eridiane da Rocha Silva and Liana de Araújo Santos) involved in this investigation for their participation, enthusiasm, and cooperation.

All authors declare no potential conflict of interest related to this article. 


\section{REFERENCES}

1. Hidalgo y Teran Elizondo R, Martín Bermudo FM, Peñaloza Mendez R, Berná Amorós G, Lara Padilla E, Berral de la Rosa FJ. Nutritional intake and nutritionalstatus in elite mexican teenagers soccer players of different ages. Nutr Hosp. 2015;32(4):1735-43.

2. Bangsbo J, Mohr M, Krustrup P. Physical and metabolic demands of training and match-play in the elite football player. J Sports Sci. 2006;24(7):665-74.

3. Spencer M, Bishop D, Dawson B, Goodman C. Physiological and metabolicresponses of repeated-sprint activities:specific to field-based team sports. Sports Med. 2005;35(12):1025-44.

4. Williams C, Rollo I. Carbohydrate Nutrition and Team Sport Performance. Sports Med. 2015;45 (Suppl 1):S13-22.

5. Burke LM, Hawley JA, Wong SH, Jeukendrup AE. Carbohydrates for training andcompetition. J Sports Sci. 2011;29(Suppl 1):S17-27.

6. Haugen TA, Tønnessen E, Seiler S. Anaerobic performance testing ofprofessional soccer players 1995-2010. Int J Sports Physiol Perform. 2013;8(2):148-56.

7. Ingebrigtsen J, Dillern T, Shalfawi SA. Aerobic capacities and anthropometric characteristics of elite female soccer players. J Strength Cond Res. 2011;25(12):3352-7.

8. García-Rovés PM, García-Zapico P, Patterson AM, Iglesias-Gutiérrez E. Nutrientintake and food habits of soccer players: analyzing the correlates of eating practice. Nutrients. 2014;6(7):2697-717.

9. Phillips SM, Sproule J, Turner AP. Carbohydrate ingestion during team gamesexercise: current knowledge and areas for future investigation. Sports Med. 2011;41(7):559-85.

10. Von Duvillard SP, Braun WA, Markofski M, Beneke R, Leithäuser R. Fluids andhydration in prolonged endurance performance. Nutrition. 2004;20(7-8):651-6.

11. Kingsley M, Penas-Ruiz C, Terry C, Russell M. Effects ofcarbohydrate-hydration strategies on glucose metabolism, sprint performance andhydration during a soccer match simulation in recreational players. J Sci Med Sport. 2014;17(2):239-43.

12. Physical status: the use and interpretation of anthropometry. Report of a WHOExpert Committee. World Health Organ Tech Rep Ser. 1995;854:1-452.

13. Jackson AS, Pollock ML. Generalized equations for predicting body density of men. Br J Nutr. 1978;40(3):497-504

14. Borg GA. Perceived exertion. Exerc Sport Sci Rev. 1974;2:131-53.

15. Zhang CQ, Si G, Chung PK, Du M, Terry PC. Psychometric properties of the Brunel Mood Scale in Chinese adolescents and adults. J Sports Sci. 2014;32(15):1465-76.

16. Rotta TM, Provenza MR, Oliveira WF. Aplicabilidade do Brums: estados de humor em atletas de voleibol e tênis no alto rendimento. Rev Bras Med Esporte. 2014;20(6):424-8.

17. Jeukendrup A. A step towards personalized sports nutrition: carbohydrateintake during exercise. Sports Med. 2014;44(Suppl 1):S25-33.

18. Currell K, Jeukendrup AE. Superior endurance performance with ingestion ofmultiple transportable carbohydrates. Med Sci Sports Exerc. 2008;40(2):275-81.

19. Jeukendrup AE, Moseley L, Mainwaring GI, Samuels S, Perry S, Mann CH. Exogenous carbohydrate oxidation during ultraendurance exercise. J ApplPhysiol (1985). 2006;100(4):1134-41.

20. Jentjens RL, Shaw C, Birtles T, Waring RH, Harding LK, Jeukendrup AE. Oxidation of combined ingestion of glucose and sucrose during exercise. Metabolism. 2005;54(5):610-8.

21. Rowlands DS, Swift M, Ros M, Green JG. Composite versus single transportable carbohydrate solution enhances race and laboratory cycling performance. Appl Physiol Nutr Metab. 2012;37(3):425-36.

22. Casa DJ, Armstrong LE, Hillman SK, Montain SJ, Reiff RV, Rich BS, et al. National athletic trainers'association position statement: fluidreplacement for athletes. J Athl Train. 2000;35(2):212-24.

23. Maughan RJ, Shirreffs SM, Leiper JB. Errors in the estimation of hydrationstatus from changes in body mass. J Sports Sci. 2007;25(7):797-804.

24. Castro-Sepulveda M, Cerda-Kohler H, Pérez-Luco C, Monsalves M, Andrade DC, Zbinden-Foncea H, et al. Hydration status afterexercise affect resting metabolic rate and heart rate variability. Nutr Hosp 2014;31(3):1273-7.

25. Phillips SM, Sykes D, Gibson N. Hydration Status and fluid balance of elite european youth soccer players during consecutive training sessions. J Sports Sci Med. 2014;13(4):817-22.

26. Castro-Sepúlveda M, Astudillo S, Álvarez C, Zapata-Lamana R, Zbinden-FonceaH, Ramírez-Campillo $\mathrm{R}$, et al. Prevalence of dehydration before training in profesionalchilean soccer players. Nutr Hosp. 2015;32(1):308-11.

27. Sociedade Brasileira de Medicina do Esporte. Modificações dietéticas, reposição hídrica, suplementos alimentares e drogas: omprovação de ação ergogênica e potenciais riscos para a saúde. Rev Bras Med Esporte. 2009;15(3):3-12.

28. Costill DL, Hargreaves M. Carbohydrate nutrition and fatigue. Sports Med. 1992;13(2):86-92.

29. Hawley JA, Dennis SC, Noakes TD. Carbohydrate, fluid, and electrolyterequirements of the soccer player: a review. Int J Sport Nutr. 1994;4(3):221-36.

30. Ribeiro HN, Fernandes ARR, Viana MS, Brandt R, Andrade A. Estadosde humor de árbitros de futebol não-profissional. Rev. Educ. Fis UEM. 2012;2(4):575-83. 